\title{
Management of complex perianal Crohn's disease
}

\author{
Lara Aguilera-Castro, Carlos Ferre-Aracil, Ana Garcia-Garcia-de-Paredes, Enrique Rodriguez-de-Santiago, \\ Antonio Lopez-Sanroman
}

University Hospital Ramón y Cajal (Affiliated to Universidad de Alcalá), Madrid, Spain

\section{Abstract}

Patients with Crohn's disease often develop perianal disease, successfully managed in most cases. However, its most aggressive form, complex perianal disease, is associated with high morbidity and a significant impairment in patients' quality of life. The aim of this review is to provide an updated approach to this condition, reviewing aspects of its epidemiology, diagnosis and therapeutic alternatives. Emerging treatment options are also discussed. A multidisciplinary assessment of these patients with a coordinated medical and surgical approach is crucial.

Keywords Crohn's disease, perianal disease, perianal fistula, perianal abscess

Ann Gastroenterol 2017; 30 (1): 1-12

\section{Introduction}

Crohn's disease (CD) is a chronic inflammatory condition, probably arising from an altered interaction between the host and environmental factors. Therapy for $\mathrm{CD}$ has seen significant developments during the last years. We have witnessed the arrival of biological therapies, the rationalizing of immunosuppression, an effective prevention of many adverse events, and the design of better surgical techniques, among others. However, CD still sometimes surprises patients and clinicians, ruthlessly affecting personal quality of life (QoL). One of the best examples of this aggressive behavior is perianal CD (PCD). Affected individuals will not only suffer from painful shortterm lesions, but can also have their QoL diminished, and even their social performance may be influenced negatively in the long run.

In this review, we have tried to provide an overview of the current aspects regarding what has been designated complex PCD (CPCD). This review will focus on perianal fistulas, its most characteristic manifestation. We hope to contribute to a better understanding of this peculiar manifestation of CD.

Gastroenterology and Hepatology Department, University Hospital Ramón y Cajal (affiliated with Universidad de Alcalá), Madrid, Spain

\section{Conflict of Interest: None}

Correspondence to: Antonio Lopez-Sanroman, Gastroenterology and Hepatology Department, University Nospital Ramon y Cajal, 28034 Madrid, Spain, e-mail: alsanroman@salud.madrid.org

Received 20 March 2016; accepted 21 September 2016; published online 27 October 2016

DOI: https://doi.org/10.20524/aog.2016.0099

\section{Definition, epidemiology and burden of CPCD}

Many patients with CD live with a considerable symptom burden despite new and better medical treatments [1]. Whenever CD affects the perianal area, it does so mainly in the form of fistulas and abscesses. The prevalence of PCD in different studies varies between $21 \%$ and $54 \%$ of CD patients; it is more frequent in cases of isolated colonic involvement (up to $41 \%$ ), versus only $12 \%$ in patients with isolated ileal disease. It has been identified as an indicator of poor prognosis and is associated with increased healthcare costs [2,3].

PCD is not a homogeneous condition. Some cases can be managed with simple medical or surgical gestures, and have no influence on the overall disease burden. However, others will require a much more aggressive approach to control the disease. There is no clear definition of CPCD, even in the latest clinical guidelines from the European Crohn's and Colitis Organization (ECCO) on the management of CD [3]. For the purpose of this review, CPCD can be defined following the criteria proposed by Sandborn [4]: "A complex fistula is high (a high fistula involves more than $2 / 3$ of the external sphincter, high intersphincteric or high transsphincteric or extrasphincteric or suprasphincteric origin of the fistula tract), may have multiple external openings, may be associated with the presence of a perianal abscess, may be associated with the presence of a rectovaginal fistula, may be associated with the presence of an anorectal stricture, and may be associated with the presence of active rectal disease at endoscopy".

Complex perianal fistulas are more difficult to treat than simple fistulas, and therapy discontinuation results in a high rate of recurrence, as shown in a St Mark's Hospital study in the pre-biologic era (1994) [5]. In this study, 87 patients with fistulizing CD were followed during 6 years from presentation. Among these, $65 \%$ had perianal fistulas, $80 \%$ of which were classified as complex. During follow up, $14 \%$ of patients failed 
to show fistula healing, and half of patients with complex fistulas eventually required a stoma, or a resection, including proctectomy. Perianal and recto-vaginal fistulas took a median of 2.6 years to heal. Another large retrospective cohort addressing the natural history of CPCD (also mainly set in the pre-biologic era, 1980 to 2000) was conducted by Molendijket al, at Erasmus Medical Centre in Rotterdam, The Netherlands [6]. They collected data from 232 patients with a median follow up of 10 years. In their experience, $78 \%$ of patients with PCD developed complex fistulas at some time. Simple fistulas healed more often than complex fistulas ( $88.2 \%$ vs. $64.6 \%)$, and the recurrence rate was higher in complex fistulas $(41.9 \%$ vs. 26.7\%). Regarding surgical outcomes, patients with complex fistulas were more likely to receive permanent fecal diversion (63.8\% vs. $26.7 \%)$ and rectum amputation (25.5\% vs. $6.7 \%)$. The authors concluded that, after protracted follow up, only one third of patients with CPCD achieved durable remission by conventional treatment strategies.

It is important to highlight that CPCD results in increased healthcare resource use and high costs. A recent Spanish retrospective multicenter study of 97 cases of CPCD, conducted in the Madrid area [2], analyzed baseline patient characteristics and treatments indicated in real-life clinical practice. Antibiotics were administered in $32.3 \%$ of cases, immunomodulators in $20.5 \%$, biological agents in $20.3 \%$, and $27 \%$ were treated surgically. The mean annual global cost per patient was $€ 8,289$. Of this expense, $75 \%$ was due to the use of pharmacological treatments (mainly biological agents); $12.4 \%$ was accounted for by hospitalizations and surgery and $7.7 \%$ by outpatient medical visits. Previous studies that addressed the direct costs of $\mathrm{CD}$ in the same area, pointed towards an average of $€ 2,104-4,464$ per patient/year (reaching $€ 10,594$ per patient/year if biologics were prescribed) [7]. Thus, the authors concluded that a relatively small percentage of patients with $C D$ (those with fistulas and CPCD) account for a large part of the overall burden and economic cost associated with the disease. Moreover, indirect costs, derived from work absenteeism and sick leave, are seldom contemplated in this type of study, but should definitely be included in the global burden of CPCD.

PCD and CPCD result in a high morbidity among young individuals; about $25 \%$ of patients with $\mathrm{CD}$ present during their childhood or adolescence, and it is estimated that one out of every three pediatric patients will develop perianal lesions. Zwintscher et al conducted a retrospective study to address the impact of PCD in this young population [8]. They studied a large cohort of patients diagnosed with pediatric inflammatory bowel disease (IBD), $63 \%$ of whom had CD. PCD was present in $4.1 \%$ of patients and $19.17 \%$ of those had complex fistulas. Pediatric patients with perianal disease were twice as likely to need surgery. In addition, they spent on average 1.3 additional days in hospital admissions, which cost US $\$ 5,838$ more when compared with hospitalizations in those without PCD.

As mentioned before, one common outcome in patients with $\mathrm{CPCD}$ is the need for surgery in cases refractory to medical therapy. There are very few studies that assess QoL after surgery for perianal fistulizing CD. Riss et al conducted a study in Vienna to assess QoL and sexual function in these patients [9]. They followed 88 consecutive cases operated for
PCD (patients with a previous stoma were excluded from the analysis). Patients completed a self-administered questionnaire, including the International Index of Erectile Function (IIEF), Female Sexual Function Index (FSFI), Short Form-12 Health Survey (SF-12), and the IBD Questionnaire (IBDQ). They were matched by age and sex with healthy controls. Patients presented worse scores on the SF-12 (including physical and mental health) and IBDQ, showing an impaired QoL compared with healthy controls. However, there were surprisingly no significant differences between the two groups in any domain of the sexual function questionnaires (IIEF and FSFI).

In conclusion, CPCD is not rare among patients with CD. It results in higher morbidity, a significant impairment in QoL in both adult and young patients, and higher costs.

\section{Classification and diagnosis of CPCD}

Typical symptoms of perianal fistulas are anal pain with defecation, perianal itching, bleeding, and discharge of pus. They should also be expected to appear in patients with a previously drained abscess. The differential diagnosis for fistulizing perianal CD includes traumatic lesions, hidradenitis suppurativa, tuberculosis, HIV infection, lymphogranuloma venereum, perianal actinomycosis, and post-rectal dermoid inclusion cyst, among others. Anal abscesses, in turn, may present with pain in the anal area, associated with fever in severe cases. They can be suspected during physical examination by observing perianal swelling, erythema, induration and fluctuation, but are sometimes less symptomatic, so that physical examination alone is insufficient to rule them out.

Classification of perianal fistulas in $\mathrm{CD}$ is important in order to determine an optimal management strategy. Several approaches have been proposed, among which Park's classification achieves the best anatomic precision. It describes five different types of fistula: superficial, intersphincteric, transsphincteric, suprasphincteric and extrasphincteric [10]. A simple system has been devised by the American Gastroenterological Association (AGA), in which fistulas are divided into simple and complex [4]. Simple fistulas are low fistulas that involve superficial tissue, and include subcutaneous and intersphincteric and intrasphincteric fistulas that remain below the dentate line, have a single opening and are not associated with perianal complications. In contrast, complex fistulas, i.e., high intersphincteric, high transsphincteric, suprasphincteric and extrasphincteric, may have multiple openings and may be associated with an abscess, proctitis, rectal stricture or connection with bladder or vagina. All types of anterior fistulas in women are generally considered complex, because of the potential genital complications.

Imaging is crucial to assess fistula anatomy, to rule out septic complications such as an abscess, to plan treatment and to monitor the therapeutic response. Pelvic magnetic resonance imaging (MRI) should be considered in all complex fistulas (Fig. 1). It offers a high accuracy in differentiating active granulation and fibrotic tissues, and precision in diagnosing septic fistula complications. Moreover, it is a noninvasive and 
radiation-free procedure. The diagnostic specificity of MRI ranges from $76-100 \%$ [11]. Its widespread use is only limited by access and cost.

Endoanal ultrasound (EUS) is a reliable alternative to MRI for diagnosing perianal fistulas. It can obtain $2 \mathrm{D}$ or $3 \mathrm{D}$ images, and local infusion of hydrogen peroxide may improve visualization [12]. Its main limitations are endoscopist expertise, the presence of rectal stenosis, and its low accuracy in visualizing higher regions such as the ischiorectal fossa. According to some authors, high-resolution 3D EUS could detect the so-called "Crohn's ultrasound fistula sign", characterized by a hypoechogenic fistula tract surrounded by a well-defined hyperechogenic area with a thin hypoechogenic edge. This sign may discriminate Crohn's fistulas from other types of fistulas [13], although this has not been substantiated in controlled studies.

A meta-analysis comparing MRI and EUS for perianal fistula assessment [14] (Table 1) included four studies and found comparable sensitivities for MRI [0.87, 95\% confidence interval (CI) 0.63-0.96] and EUS (0.87, 95\% CI 0.70-0.95), although the specificity for MRI $(0.69,95 \%$ CI $0.51-0.82)$ was higher than that for EUS (0.43, 95\% CI 0.21-0.69). Transperineal ultrasound may represent another method for detecting perianal complications in CD. There are several studies that report a high sensitivity (up to 85\%) for the diagnosis of perianal and recto-vaginal fistulas [15].

Examination under anesthesia (EUA) is considered by ECCO guidelines as the gold standard when performed by an experienced colorectal surgeon. It has an accuracy of $90 \%$ for establishing the diagnosis of perianal disease [16]. This procedure allows immediate therapeutic intervention such as drain abscesses, seton placement or fistulotomy. If an abscess is suspected, EUA should not be delayed (Fig. 2).

Several studies have compared the suitability of MRI, EUS and EUA for CPCD diagnosis. In a prospective study of 32 patients, accuracies of $87 \%, 91 \%$ and $91 \%$, respectively, were reported [16]. The combination of EUA with either MRI or EUS improved the accuracy of the initial assessment to reach
$100 \%$ [16]. Another study found that MRI was more sensitive (0.97, 95\% CI 0.92-1.01) than clinical examination $(0.75,95 \%$ CI $0.65-0.86)$ but comparable to EUS (0.92, 95\% CI 0.85-0.99) in differentiating complex from simple disease [17].
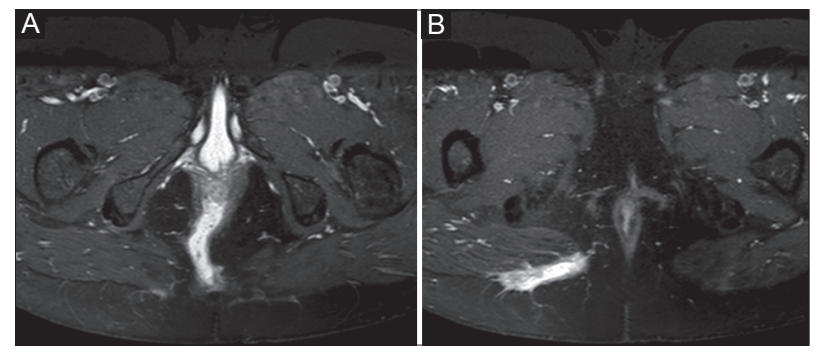

Figure 1 Transsphincteric fistula. Axial T1-weighted image (A) demonstrated high signal intensity tract $(13 \mathrm{~cm}$ in length) under puborectalis muscle. Axial T-weighted image (B) in the same patient illustrates the progression fistula to the gluteal cleft

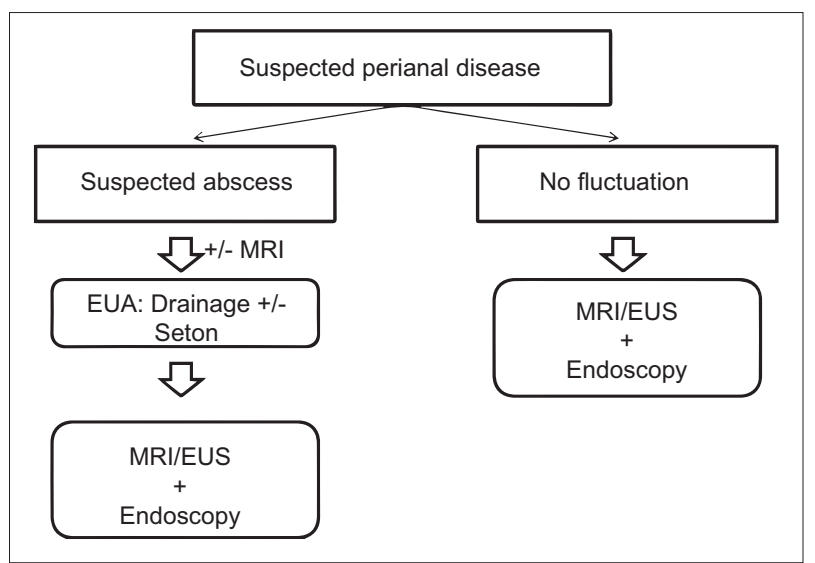

Figure 2 Diagnostic algorithm for complex perianal Crohn's disease. If abscess is suspected, MRI may be used as a diagnostic method, if readily available, before drainage [18] MRI, magnetic resonance imaging; EUS, endoanal ultrasound; EUA, examination under anesthesia

Table 1 MRI, EUS, transperineal ultrasound and EUA trials for fistulizing Crohn's disease

\begin{tabular}{|c|c|c|c|}
\hline Authors and study design & Group 1 & Group 2 & Results \\
\hline $\begin{array}{l}\text { Siddiqui et al }[14] \\
\text { Meta-analysis: four } \\
\text { randomized trials }(\mathrm{n}=481)\end{array}$ & MRI & EUS & $\begin{array}{l}\text { MRI: Sensitivity } 0.87 \text { (95\% CI } 0.63-0.96 \text { ) and specificity } \\
0.69 \text { ( } 95 \% \text { CI } 0.51-0.82 \text { ) in detecting fistulas } \\
\text { EUS: Sensitivity } 0.87 \text { (95\% CI } 0.70-0.95 \text { ) and specificity } \\
0.43 \text { ( } 95 \% \text { CI } 0.21-0.69 \text { ) in detecting fistulas }\end{array}$ \\
\hline $\begin{array}{l}\text { Maconi et al[15] } \\
\text { Prospective, } \\
\text { blind-comparison }(n=46)\end{array}$ & $\begin{array}{l}\text { Transperineal ultrasound } \\
\text { in the detection of perianal } \\
\text { and recto-vaginal fistulas } \\
\text { compared with results of EUS }\end{array}$ & $\begin{array}{l}\text { No comparison } \\
\text { arm }\end{array}$ & Transperineal ultrasound: Sensitivity $84.9 \%$ \\
\hline $\begin{array}{l}\text { Schwartz et al }[16] \\
\text { Prospective, } \\
\text { blind-comparison }(\mathrm{n}=34)\end{array}$ & MRI, EUS and EUA & & $\begin{array}{l}\text { Accuracy } \\
\text { MRI } 87 \% \text { (95\% CI 69-96\%), EUS 91\% (95\% CI 75-98\%) } \\
\text { and EUA } 91 \% \text { (95\% CI 75-98\%) }\end{array}$ \\
\hline $\begin{array}{l}\text { Sahni et al }[17] \\
\text { Systematic review: } 2 \text { studies } \\
(\mathrm{n}=156)\end{array}$ & MRI & EUS & $\begin{array}{l}\text { MRI: Sensitivity } 0.97 \text { (95\% CI } 0.92-1.01 \text { ) and specificity } \\
0.96 \text { ( } 95 \% \text { CI } 0.90-1.02) \\
\text { EUS: Sensitivity } 0.92 \text { (95\% CI } 0.85-0.99 \text { ) and specificity } \\
0.85 \text { ( } 95 \% \text { CI } 0.75-0.95)\end{array}$ \\
\hline
\end{tabular}

MRI, magnetic resonance imaging; EUS, endoanal ultrasound; EUA, examination under anesthesia; $95 \%$ CI, 95\% confidence interval 
Fistulography and CT should not be routinely used for the diagnosis and classification of CPCD. Their main limitations are the use of ionizing radiations and the poor resolution in differentiating fistulas and pelvic floor muscles [18]. Additionally, fistulography is not devoid of complications.

Proctosigmoidoscopy should be performed in all patients with CPCD, in order to determine the extent and severity of inflammation, and to rule out complications such as strictures and cancer [18]. The presence of proctitis has consistently been associated with non-healing of fistula tracts and with a higher proctectomy rate [5].

Different methods and indexes have been proposed to clinically measure the activity of fistulas. The perianal disease activity index (PDAI) score includes the evaluation of 5 elements: fistula discharge, pain and restriction of activities, sexual activity restriction, type of perianal disease, and degree of induration (Table 2) [19]. A PDAI score $>4$ suggests active fistula drainage or local inflammation, with an accuracy of $87 \%$ [20]. This score has been validated in several clinical trials [21]. A simple way to evaluate fistula activity is the so-called "fistula drainage assessment" based on the examiner's perception. It classifies fistulas as "open" if pus discharge is observed after digital compression. Clinical improvement or response is achieved if there is a reduction of $50 \%$ or more in the number of draining fistulas in two consecutive visits, and remission is established when draining fistulas are absent in two consecutive visits.

External openings sometimes heal while inflammatory changes persist in the fistula tracts. For this reason, the use of MRI or EUS to monitor the evolution of CPCD after medical and surgical therapy is generally recommended. In 2003, van Assche proposed an MRI-based score, clinically validated but showing a poor correlation with PDAI [22].

\section{Treatment of CPCD}

It is important to stress a few points when approaching a patient with PCD:

a) PCD is very frequent and its symptoms can be disproportionately mild relative to its anatomic aggressiveness. Therefore, a thorough clinical examination of the perianal region has to be performed at the first contact with a patient who has suspected or known CD, and should be repeated from time to time, especially if new symptoms develop.

b) The diagnosis of PCD has to be followed first by an immediate damage control policy. This involves the treatment of local infection, which is always a factor that contributes to patients' discomfort and anal sphincter destruction. Antibiotics are generally prescribed at this stage, usually a combination of ciprofloxacin and metronidazole. Amoxicillin-clavulanate, or even parenteral imipenem or piperacillin-tazobactam may be preferred if the septic component is predominant ("pelvic sepsis").

c) Drainage of a perianal abscess, if present, is essential to control local infection.

d) Steroids do not play a role in managing PCD and must be actively avoided.
Table 2 Perianal disease activity index [19]

\begin{tabular}{|c|c|}
\hline Item & Points \\
\hline \multicolumn{2}{|l|}{ Discharge } \\
\hline No discharge & 0 \\
\hline Minimal mucous discharge & 1 \\
\hline Moderate mucous or purulent discharge & 2 \\
\hline Substantial discharge & 3 \\
\hline Gross fecal soiling & 4 \\
\hline \multicolumn{2}{|l|}{ Pain/restriction of activities } \\
\hline No activity restriction & 0 \\
\hline Mild discomfort, no restriction & 1 \\
\hline Moderate discomfort, some limitation & 2 \\
\hline Marked discomfort, marked limitation & 3 \\
\hline Severe pain, severe limitation & 4 \\
\hline \multicolumn{2}{|l|}{ Restriction of sexual activity } \\
\hline No restriction of sexual activity & 0 \\
\hline Slight restriction of sexual activity & 1 \\
\hline Moderate limitation of sexual activity & 2 \\
\hline Marked limitation of sexual activity & 3 \\
\hline Unable to engage in sexual activity & 4 \\
\hline \multicolumn{2}{|l|}{ Type of perianal disease } \\
\hline No perianal disease & 0 \\
\hline Anal fissure or mucosal tear & 1 \\
\hline$<3$ perianal fistulas & 2 \\
\hline$>3$ perianal fistulas & 3 \\
\hline $\begin{array}{l}\text { Anal sphincter ulceration or fistulas with significant } \\
\text { undermining skin }\end{array}$ & 4 \\
\hline \multicolumn{2}{|l|}{ Degree of induration } \\
\hline No induration & 0 \\
\hline Minimal induration & 1 \\
\hline Moderate induration & 2 \\
\hline Substantial induration & 3 \\
\hline Gross fluctuance/abscess & 4 \\
\hline
\end{tabular}

e) A therapeutic plan has to be laid out, and it should involve a surgical consultation in almost all cases.

f) As part of this therapeutic plan, a complete study should be ordered, including thiopurine methyltransferase assay, hepatitis $\mathrm{B}$ and $\mathrm{C}$ virus serologies, and diagnosis of latent tuberculosis according to local recommendations, among others.

\section{Surgery}

Although this is a gastroenterological review, it needs to be stressed that the management of CPCD is never complete without a surgical consultation. In more fortunate patients the 
surgeon will just stand by. More frequently, surgery is needed to accomplish disease control. Perhaps more importantly, surgery can be the last and only resort in ultra-refractory patients.

Commonly, the surgeon's first participation is related to abscess drainage. In early stages, surgical gestures should be conservative in order to prevent the destruction of muscular tissue and to preserve anal function. Debris evacuation may be achieved by the insertion of simple drains in the presence of abscesses. The use of setons is generally avoided at this stage, and their placement can be performed more safely after the abscess has been evacuated and the anatomy of the fistula has been outlined with imaging techniques and endoscopy. It has to be emphasized that medical therapy attempted without a proper surgical counterpart will be less successful and sometimes risky.

The exact timing for seton placement and removal is a matter of ongoing controversy; in fact, ECCO guidelines do not specify a time interval. As mentioned above, setons are sometimes avoided in emergency surgery, and can be more safely placed once local sepsis has been controlled, by a more experienced surgeon, and after imaging techniques and endoscopy have outlined the anatomy of fistulous disease [23]. Setons can be left in place for as long as necessary, even for months, and the decision to extract them has to be taken individually during one of the several follow-up surgical visits that will generally be needed. A recent systematic review performed by Joline de Groof et al included 10 non-controlled studies, with a total of 305 patients treated with setons [24]. Complete fistula closure rate varied between $13.6-100 \%$ and recurrence ranged from $0-83 \%$. Seton removal was always decided by the surgeon, and was performed between 3 weeks and 40 months following placement. Some recent studies suggest that seton removal after complete induction with anti-tumor necrosis factor (TNF)- $\alpha$, or at least after the fifth dose of infliximab, may be beneficial in terms of a lower recurrence rate [25]. Any combination of seton placement, immunomodulators, and anti-TNF- $\alpha$ seems to achieve better results than seton placement alone [24].

EUA is the gold standard for identifying the disposition and anatomical relationships of fistulas, although it should be complemented by imaging techniques [16]. The importance of relying on an experienced surgeon cannot be underestimated. Perianal anatomy is not simple, and the temptation to do more than is strictly needed must be avoided. In a few cases, the complexity of the perianal disease is so high, and tissue destruction so significant, that a temporary ileostomy will be the best option for controlling structural damage and alleviating the patient's condition [26]. This will allow tissue healing, and transit may be reconstructed in the future.

During medical therapy, failure to respond to treatment or the onset of new symptoms may sometimes warrant a second EUA. This is very important if major changes in therapy are considered, such as progressing from immunomodulators to biological agents, or the use of advanced therapies.

Cases refractory to medical therapy may be managed surgically. This is clearly beyond the scope of this review, and the reader should look into recent and comprehensive papers [27]. Several techniques, such as advancement flap, laser therapy, and ligation of the intersphincteric fistula tract, among others, can be attempted, but only by an experienced surgical team.

Definitive fecal diversion with colostomy or ileostomy is sometimes the only resort [26,28]. Careful consideration should be given on a case-by-case basis to the possibility of completing this by proctectomy. Persistence of rectal inflammation (sometimes manifested as peristomal pyoderma), the possibility of malignization and the maintenance of some fistulas by the presence of the rectal stump, all would argue in favor of proctectomy. The distinct possibility of adverse outcomes of proctectomy [29], such as erectile dysfunction in men, or the appearance of a persistent perineal sinus after rectal excision, should always be kept in mind.

\section{Antibiotics}

Other than for controlling perianal sepsis, as stated above, antibacterial agents are recommended in the treatment of perianal fistulas in CD. However there are discrepancies in their indications, and it is unclear whether they really represent a complete therapeutic alternative in the treatment of complex fistulas [30]. In our view, they should never be used alone. For complex fistulas, ECCO guidelines suggest that antibiotics should be used as the first line of therapy in combination with azathioprine or mercaptopurine [3]. Antibiotics are effective for improving symptoms; however, they do not usually induce complete healing.

Metronidazole and ciprofloxacin are the preferred agents. Usual doses include metronidazole $20 \mathrm{mg} / \mathrm{kg} /$ day, or 750 $1000 \mathrm{mg} /$ day divided into 3 or 4 doses, or ciprofloxacin 1000$1500 \mathrm{mg} /$ day divided into 2 doses. There are no suggestions relative to treatment duration, but in most studies therapy lasts for 8-12 weeks. The drugs can also be used in combination.

Despite the recommendations, the efficacy of antibiotics alone for the treatment of PCD is based only on uncontrolled trials, case series, and one short good-quality trial. The latter was a randomized, double-blinded, placebo-controlled trial that included only 25 patients and compared ciprofloxacin, metronidazole and placebo for 10 weeks [31] (Table 3). Remission and response occurred more often in patients receiving ciprofloxacin, but the differences were not significant.

The use of antibiotics in association with immunomodulators or biologics has also been analyzed. In a prospective openlabel trial, a combination of antibiotics (metronidazole or ciprofloxacin) and azathioprine was superior to antibiotics alone in achieving a response at week 20 [32]. A doubleblind, placebo-controlled study of 24 patients showed that a combination of ciprofloxacin and infliximab (IFX) tended to be more effective than IFX alone [33]. The combination of antibiotics and adalimumab (ADA) has also been studied in a randomized, double-blind, placebo-controlled trial that included 76 patients. Clinical response was observed in $71 \%$ of patients treated with ADA plus ciprofloxacin and in $47 \%$ treated with ADA plus placebo $(\mathrm{P}=0.047)$. However, at week 24 no difference was observed in the clinical response between the two groups [34]. 
Table 3 Antibiotic trials for fistulizing Crohn's disease

\begin{tabular}{|c|c|c|c|}
\hline Authors and study design & Group 1 & Group 2 & Results \\
\hline $\begin{array}{l}\text { Thia et al[31] } \\
\text { Multicenter, prospective, double-blind, } \\
\text { placebo-controlled study }(\mathrm{n}=25)\end{array}$ & $\begin{array}{l}\text { Ciprofloxacin ( } 500 \mathrm{mg} \text { b.i.d.) or } \\
\text { metronidazole ( } 500 \mathrm{mg} \text { b.i.d.) for } \\
10 \text { weeks }\end{array}$ & Placebo for 10 weeks & $\begin{array}{l}\text { Ciprofloxacin } 40 \% \text { response } \\
\text { vs. metronidazole } 14.3 \% \text { vs. } \\
\text { placebo } 12.5 \%(\mathrm{P}=0.43)\end{array}$ \\
\hline $\begin{array}{l}\text { Dejaco et al [32] } \\
\text { Prospective, open-label study }(n=52)\end{array}$ & $\begin{array}{l}\text { Ciprofloxacin }(500-1000 \mathrm{mg} / \text { day }) \\
\text { and/or metronidazole } \\
(1000-1500 \mathrm{mg} / \text { day }) \text { for } 8 \text { weeks }\end{array}$ & $\begin{array}{l}\text { Ciprofloxacin } \\
(500-1000 \mathrm{mg} / \text { day }) \text { and/or } \\
\text { metronidazole } \\
(1000-1500 \mathrm{mg} / \text { day }) \\
\text { for } 8 \text { weeks, plus } \\
\text { azathioprine }(2-2.5 \mathrm{mg} / \mathrm{kg}) \\
\text { from } 0 \text { or } 8 \text { week }\end{array}$ & $\begin{array}{l}\text { Azathioprine group } 48 \% \\
\text { response vs. no azathioprine } \\
\text { group } 15 \%(\mathrm{P}=0.03)\end{array}$ \\
\hline $\begin{array}{l}\text { West et al[33] } \\
\text { Prospective, doubled-blind, } \\
\text { placebo-controlled study }(\mathrm{n}=24)\end{array}$ & $\begin{array}{l}\text { Ciprofloxacin ( } 1000 \mathrm{mg} / \text { day) for } \\
12 \text { weeks plus infliximab } 5 \mathrm{mg} / \mathrm{kg} \\
\text { at weeks } 6,8 \text { and } 12\end{array}$ & $\begin{array}{l}\text { Placebo for } 12 \text { weeks plus } \\
\text { infliximab } 5 \mathrm{mg} / \mathrm{kg} \text { at } \\
\text { weeks } 6,8 \text { and } 12\end{array}$ & $\begin{array}{l}\text { Ciprofloxacin group } 73 \% \\
\text { response vs. placebo } \\
\text { group 39\% }(\mathrm{P}=0.12)\end{array}$ \\
\hline $\begin{array}{l}\text { Dewint et al[34] } \\
\text { Prospective, doubled-blind, } \\
\text { placebo-controlled study }(\mathrm{n}=76)\end{array}$ & $\begin{array}{l}\text { Ciprofloxacin } \\
\text { ( } 500 \mathrm{mg} \text { b.i.d.) for } 12 \text { weeks plus } \\
\text { adalimumab ( } 160 / 80 \mathrm{mg} \text { week } 0 \text {, } \\
2 \text { and } 40 \mathrm{mg} \text { every other week) } \\
\text { for } 24 \text { weeks }\end{array}$ & $\begin{array}{l}\text { Placebo for } 12 \text { weeks plus } \\
\text { adalimumab ( } 160 / 80 \mathrm{mg} \\
\text { week } 0,2 \text { and } 40 \mathrm{mg} \text { every } \\
\text { other week) for } 24 \text { weeks }\end{array}$ & $\begin{array}{l}\text { Ciprofloxacin group } 71 \% \\
\text { response vs. placebo } \\
\text { group } 47 \%(\mathrm{P}=0.047)\end{array}$ \\
\hline $\begin{array}{l}\text { Maeda et al[35] } \\
\text { Prospective, doubled-blind, } \\
\text { placebo-controlled study }(\mathrm{n}=74)\end{array}$ & $\begin{array}{l}\text { Metronidazole } 10 \% \text { ointment } \\
\text { t.i.d. for } 4 \text { weeks }\end{array}$ & $\begin{array}{l}\text { Placebo ointment for } \\
4 \text { weeks }\end{array}$ & $\begin{array}{l}\text { Reduction in PCDAI } \\
\text { score of at least } 5 \text { points in } \\
\text { metronidazole group } 10 \text { of } \\
27 \text { vs. placebo group } 4 \text { of } \\
34(\mathrm{P}=0.031)\end{array}$ \\
\hline
\end{tabular}

PDAI, perianal Crohn's disease activity index

Topical antibiotics were studied in a blinded, randomized, placebo-controlled study of 74 patients that compared $10 \%$ metronidazole ointment versus placebo during 4 weeks. Metronidazole was not effective in the reduction of PDAI score, but perianal discharge was reduced significantly [35].

\section{Immunomodulatory agents}

\section{Thiopurines}

No randomized controlled trials have evaluated the effectiveness of thiopurines for the treatment of perianal complex fistulas. Available data come from case series and from a meta-analysis of five randomized, placebo-controlled trials that assessed perianal fistula closure as secondary endpoint. In those, thiopurines (azathioprine 2-3 $\mathrm{mg} / \mathrm{kg}$ and 6-mercaptopurine $1.5 \mathrm{mg} / \mathrm{kg}$ ) seemed effective in inducing remission of perianal fistulas (odds ratio 4.44, 95\% CI 1.5-13.20) [36] (Table 4). Even though thiopurines may be effective, this may take weeks or even months. Therefore, some studies have evaluated their role in combination with antibiotics or anti-TNF agents. A prospective trial evaluated the role of azathioprine in maintaining response after 8 weeks of antibiotics (ciprofloxacin or metronidazole), finding a higher response rate in those patients who were maintained on azathioprine after antibiotics withdrawal (48\% vs. $15 \%, \mathrm{P}=0.03$ ) [32]. Studies of thiopurines in combination with IFX indicate that they may have a beneficial role in improving response. Despite the lack of controlled trials, ECCO guidelines recommend antibiotics with surgical drainage and maintenance therapy with thiopurines as first-line therapy for CPCD [3].
They should probably be used for facilitating and maintaining response in combination with anti-TNF agents.

\section{Calcineurin inhibitors}

Tacrolimus $(0.2 \mathrm{mg} / \mathrm{kg} /$ day) in a small placebo-controlled trial was shown to be effective in improving symptoms ( $43 \%$ vs. $8 \%, \mathrm{P}<0.05)$, but not in achieving complete fistula closure [37]. A more recent study evaluated the role of tacrolimus in severe CD intolerant or unresponsive to anti-TNF agents [38]. It included 15 patients with perianal fistulas, and a milder discharge was observed in five of them. Tacrolimus levels of 10-15 ng/mL were associated with better therapeutic results, with avoidance or delay of surgery. In patients not responding to anti-TNF therapy, tacrolimus may be used as rescue therapy before considering an aggressive surgical option.

In a retrospective study, intravenous cyclosporine followed by oral cyclosporine achieved complete closure in 4 of 13 patients, but the response was lost after drug discontinuation [39]. Due to the limited data, this drug it is not a clear therapeutic option in CPCD.

\section{Other}

Small case series suggest that methotrexate may be effective for fistulizing CD [40]. However, it has not been specifically studied in CPCD; therefore, methotrexate can not be recommended nowadays.

Thalidomide has been used as a rescue therapy, given its ability to inhibit TNF- $\alpha$, interferon- $\gamma$ and interleukin (IL)-12, 
Table 4 Immunomodulatory agents trials, metanalysis or systematic reviews for fistulizing Crohn's disease

\begin{tabular}{|c|c|c|c|}
\hline Authors and study design & Group 1 & Group 2 & Results \\
\hline $\begin{array}{l}\text { Pearson et al[36] } \\
\text { Meta-analysis: nine randomized, } \\
\text { placebo-controlled trials of } \\
\text { azathioprine or 6-mercaptopurine } \\
\text { therapy }\end{array}$ & $\begin{array}{l}\text { Azathioprine or } \\
\text { 6-mercaptopurine }\end{array}$ & Placebo & $\begin{array}{l}\text { Fistulas improved with azathioprine } \\
\text { or 6-mercaptopurine therapy } \\
\text { (odds ratio } 4.44 ; 95 \% \text { CI } 1.50 \text { to } 13.20 \text { ) }\end{array}$ \\
\hline $\begin{array}{l}\text { Sandborn et al [37] } \\
\text { Multicenter, prospective, } \\
\text { double-blind, placebo-controlled } \\
\text { study }(n=48)\end{array}$ & $\begin{array}{l}\text { Oral tacrolimus }(0.20 \mathrm{mg} / \mathrm{kg} / \text { day }) \\
\text { for } 10 \text { weeks }\end{array}$ & Placebo for 10 weeks & $\begin{array}{l}\text { Tacrolimus } 43 \% \text { response vs. placebo } \\
8 \%(\mathrm{P}=0.004)\end{array}$ \\
\hline $\begin{array}{l}\text { Cat et al[39] } \\
\text { Retrospective }(n=20)\end{array}$ & $\begin{array}{l}\text { Intravenous cyclosporine } \\
(4 \mathrm{mg} / \mathrm{kg} / \text { day) for the first week, } \\
\text { followed by oral cyclosporine at } 8 \\
\mathrm{mg} / \mathrm{kg} / \text { day }\end{array}$ & No comparison arm & $\begin{array}{l}80 \% \text { patients had symptomatic } \\
\text { improvements on days } 15 \text { and } 30 \\
\text { At } 3,6,7 \text {, and } 20 \text { months } 45 \% \text { of } \\
\text { fistulas were closed }\end{array}$ \\
\hline $\begin{array}{l}\text { Yang et al }[41] \\
\text { Systematic review: } 4 \text { case } \\
\text { series }(n=40)\end{array}$ & Thalidomide (50-300 mg/day) & No comparison arm & $\begin{array}{l}25 \% \text { achieved remission, } 27.5 \% \text { partial } \\
\text { response and } 35 \% \text { withdrew from the } \\
\text { study due to adverse events }\end{array}$ \\
\hline
\end{tabular}

95\% CI, 95\% confidence interval

among others. It has been evaluated in uncontrolled studies for refractory $\mathrm{CD}$, and some of these included patients with perianal fistulas. In 2015, Yang et al performed a systematic review of its efficacy in IBD [41]. They included 4 case series with a total of 40 patients with PCD who were treated with thalidomide (50-300 mg/day) as induction therapy. Ten patients achieved complete remission, 11 had a partial response, while five patients had no response. The remaining 14 subjects had to stop thalidomide because of side effects. Case reports and case series have reported some benefit of mycophenolate mofetil, but neither this nor thalidomide can be recommended for standard clinical practice.

\section{Biological therapy}

\section{Anti-TNF agents}

Anti-TNF agents have achieved the best available evidence for the treatment of CPCD. However, there are still some aspects regarding their use that require further evaluation, such as the need for concomitant antibiotics, thiopurines and seton placement. Even though anti-TNF agents are recommended by ECCO guidelines as second-line therapy for induction and maintenance treatment in patients refractory to thiopurines and antibiotics [3], most experts advocate a "top-down" strategy with anti-TNF as the initial treatment of choice for induction therapy in CPCD [18]. Antibiotics should probably be used concomitantly in induction and thiopurines in maintenance therapy, which should be maintained for at least one year. Rates around $11 \%$ of perianal abscess formation under antiTNF therapy have been described [42] (Table 5). Consequently, it is important to drain abscesses prior to treatment in order to avoid septic complications and optimize therapeutic results.

IFX is the only medical treatment that has proved to be effective in inducing the closure of complex perianal fistulas in a randomized controlled trial specifically designed and powered for this endpoint. In that study, 5 or $10 \mathrm{mg} / \mathrm{kg}$ of IFX at weeks 0,2 and 6 achieved a response in $62 \%$ of patients, compared to $26 \%$ in the placebo group. Complete closure of all fistulas was observed in $55 \%$ of patients receiving the $5 \mathrm{mg} / \mathrm{kg}$ dose compared to $13 \%$ in the placebo group [42]. Another randomized placebocontrolled trial evaluated the efficacy of IFX in maintenance therapy ( $5 \mathrm{mg} / \mathrm{kg}$ every 8 weeks for one year) in patients who had previously responded to IFX induction, finding that $36 \%$ of patients had a complete absence of draining fistulas at week 54 compared to $19 \%$ in the placebo group $(\mathrm{P}=0.009)$ [43]. Other noncontrolled studies have reported good results for IFX as induction and maintenance therapy, with rates of complete cessation of fistula drainage ranging from 13-90\% [44]. Maintenance therapy with IFX significantly reduces hospitalizations and surgeries, and should be used by default [45]. As discussed above, antibiotics may be useful as adjuvant therapy with anti-TNF agents. Even though IFX therapy offers the best results, there is a discrepancy between clinical remission and persistent fistula activity on imaging. MRI or ultrasound studies show that fistula healing only occurs in a small minority and that tracks persist. In one study, $54 \%$ of patients had a clinical response with cessation of drainage, but fistula inactivity was detected on ultrasound in only $18 \%$ [46]. This may contribute to the high rate of recurrence when treatment is stopped after one year in patients with complex fistula in clinical remission, suggesting the need for a longer period of treatment and the use of image studies before considering treatment discontinuation. Interestingly, a recent study presented at Digestive Disease Week 2016 suggests that the IFX levels needed for fistula healing are greater than those needed for mucosal healing [47].

Regarding ADA, complete closure and fistula improvement was evaluated as a secondary endpoint in three randomized controlled trials comparing this drug to placebo. The most recent one included 117 patients with actively draining perianal fistulas, who were randomized to 
Table 5 Biological therapy trials for fistulizing Crohn's disease

\begin{tabular}{|c|c|c|c|}
\hline Authors and study design & Group 1 & Group 2 & Results \\
\hline $\begin{array}{l}\text { Present et al[42] } \\
\text { Multicenter, prospective, double-blind, } \\
\text { placebo-controlled study }(n=94)\end{array}$ & $\begin{array}{l}\text { Infliximab } 5 \mathrm{mg} / \mathrm{kg} \text { at } 0,2 \mathrm{and} \\
6 \text { weeks or infliximab } 10 \mathrm{mg} / \mathrm{kg} \text { at } \\
0,2 \text { and } 6 \text { weeks }\end{array}$ & Placebo & $\begin{array}{l}\text { Complete closure of all fistulas: } \\
5 \mathrm{mg} / \mathrm{kg} \text { dose: } 55 \%, 10 \mathrm{mg} / \mathrm{kg} \\
\text { dose: } 38 \% \text { and placebo: } 13 \%\end{array}$ \\
\hline $\begin{array}{l}\text { Sands et al[43] } \\
\text { Multicenter, prospective, double-blind, } \\
\text { placebo-controlled study }(n=195)\end{array}$ & $\begin{array}{l}\text { Infliximab } 5 \mathrm{mg} / \mathrm{kg} \text { every } 8 \text { weeks } \\
\text { for } 54 \text { weeks }\end{array}$ & $\begin{array}{l}\text { Placebo every } \\
8 \text { weeks for } 54 \text { weeks }\end{array}$ & $\begin{array}{l}\text { Cessation of drainage: Infliximab } \\
\text { group: } 36 \% \text { vs. placebo groups } \\
19 \%(\mathrm{P}=0.009)\end{array}$ \\
\hline $\begin{array}{l}\text { Schwartz et al [44] } \\
\text { Retrospective }(\mathrm{n}=21)\end{array}$ & $\begin{array}{l}\text { Ciprofloxacin }(1000 \mathrm{mg} / \mathrm{day}) \text {, } \\
\text { azathioprine }(2-2.5 \mathrm{mg} / \mathrm{kg} / \mathrm{day}) \text { or } \\
6 \text {-mercaptopurine }(1-1.5 \mathrm{mg} / \mathrm{kg} / \\
\text { day) and infliximab }(5 \mathrm{mg} / \mathrm{kg} \text { at } 0,2 \\
\text { and } 6 \text { week and then every } 8 \text { weeks })\end{array}$ & No comparison arm & $\begin{array}{l}\text { Cessation of drainage: initial } 86 \% \\
\text { and long-term } 76 \%\end{array}$ \\
\hline $\begin{array}{l}\text { Colombel et al[ } 48] \\
\text { Multicenter, prospective, double-blind, } \\
\text { placebo-controlled study }(n=117)\end{array}$ & $\begin{array}{l}\text { Adalimumab ( } 160 / 80 \mathrm{mg} \text { at } \\
0 / 2 \text { weeks) and then } 40 \mathrm{mg} \text { weekly }\end{array}$ & $\begin{array}{l}\text { Adalimumab } \\
(160 / 80 \mathrm{mg} \text { at } \\
0 / 2 \text { weeks }) \text { and then } \\
\text { placebo }\end{array}$ & $\begin{array}{l}\text { Cessation of drainage: } \\
\text { Adalimumab group: } 33 \% \text { and } \\
\text { placebo group: } 13 \%(\mathrm{P}=0.016)\end{array}$ \\
\hline $\begin{array}{l}\text { Schreiber et al[ } 49] \\
\text { Multicenter, prospective, double-blind, } \\
\text { placebo-controlled study }(n=58)\end{array}$ & $\begin{array}{l}\text { Certolizumab pegol } \\
\text { (400 mg monthly) }\end{array}$ & Placebo & $\begin{array}{l}\text { Cessation of drainage: } \\
\text { Certolizumab pegol group: } 36 \% \\
\text { vs. placebo group: } 17 \%(\mathrm{P}=0.038)\end{array}$ \\
\hline $\begin{array}{l}\text { Sandborn et al[50] } \\
\text { Multicenter, prospective, double-blind, } \\
\text { placebo-controlled study }(n=165)\end{array}$ & $\begin{array}{l}\text { Vedolizumab }(300 \mathrm{mg}) \text { every } 4 \text { or } \\
8 \text { weeks }\end{array}$ & Placebo & $\begin{array}{l}\text { Cessation of drainage: } \\
\text { Vedolizumab group: } 41.2 \% \text { vs. } \\
\text { placebo group } 11 \% \%(\mathrm{P}=0.03)\end{array}$ \\
\hline
\end{tabular}

receive $\mathrm{ADA}$ or placebo for one year after induction with $\mathrm{ADA}$; fistula remission was higher in the ADA group at week 56 (33\% vs. $13 \%, \mathrm{P}<0.02)$ [48].

There are no randomized placebo controlled trials specifically designed to examine the efficacy of certolizumab pegol in perianal disease but its efficacy has been reported as a secondary endpoint. One trial evaluated maintenance therapy with certolizumab pegol versus placebo after response to induction with certolizumab, finding that $36 \%$ of patients in the treatment group achieved complete closure of perianal fistulas versus $17 \%$ in the placebo group $(\mathrm{P}=0.038)$ [49].

\section{Other biological therapies}

There is limited data regarding the efficacy of vedolizumab in perianal disease, with inconclusive results. A randomized controlled trial designed to evaluate the efficacy of vedolizumab in $\mathrm{CD}$ found that vedolizumab every 8 weeks achieved a significantly higher rate of draining fistula closure compared to placebo (41.2\% vs. $11 \%, \mathrm{P}=0.03$ ) [50].

Ustekinumab is an anti-IL-12/IL-23 monoclonal antibody that has shown its efficacy in Crohn's disease in phase IIb and phase III clinical trials; unfortunately, these trials do not address its role in PCD [51]. To date, the most extensive data come from a recently published observational study. In 2016 Wils et al performed a multicenter retrospective analysis that included 12 patients with PCD; 8 of them experienced clinical improvement, as defined by physician's global assessment, the probability of remaining corticosteroid/surgery free, and no additional immunosuppression [52].

\section{Other treatments}

In recent decades, several new kinds of treatments have emerged in the hope of offering an alternative for those patients unresponsive to standard therapy. However, their place in the therapeutic algorithm and their real-world clinical applicability remain to be seen, since most of the available data come from studies with a high risk of bias.

\section{Hyperbaric oxygen therapy (HOT)}

HOT involves breathing $100 \%$ oxygen while under increased atmospheric pressure. This leads to an increase in the plasma $\mathrm{O}_{2}$ partial pressure, thus enhancing oxygenation of hypoxic bowel tissues and also of non-healing perianal fistulas. In addition, it has been reported that HOT may have immunomodulatory properties, reducing IL-1, IL-2 and TNF- $\alpha$ levels [53] and upregulating molecular pathways (hypoxiainducible factor-1, heme oxygenase-1) with an essential role in hypoxia tolerance [54].

In 2014, Dulai et al performed a systematic review of the efficacy and safety of HOT in IBD [55]. They incorporated data from 17 different studies, most of which were case reports, with only one randomized clinical trial. In their analysis they included 40 patients with PCD for a median of 2 years prior to initiation of HOT; 21 had fistulas, with a predominance of complex fistulas. Most of these patients responded poorly to 5-aminosalicylic acid, steroids and immunomodulatory therapy. The overall response rate was $88 \%$ (18/40 complete healing, $17 / 40$ partial healing), while two patients abandoned the treatment because of side effects. It should be highlighted 
that there was high heterogeneity in the assessment of response to therapy, symptom evaluation, number of sessions and time of follow up.

Adverse effects are uncommon (0.01\%) and it seems that HOT is better tolerated than in other indications, such as radiation proctitis $(0.2 \%)$. Eardrum perforation and psychological intolerance (claustrophobia) are the most frequent side effects. Pneumothorax, myopia, bowel perforation and seizures have also been described [55].

Since the completion of this systematic review no further relevant data have emerged.

\section{Mesenchymal stem cells (MSCs)}

MSCs are non-hematopoietic multipotent cells with powerful anti-inflammatory, immunomodulatory and fibroblast-like healing properties. Currently, both allogenic and autologous MSCs derived from fat or bone marrow have been used in PCD [56]. There are already available data from several phase II clinical trials, confirming that this therapeutic approach is safe and probably useful for some patients. Subjects included in these studies were highly heterogeneous, most of them refractory to thiopurines and anti-TNF drugs, and obtained variable rates of fistula closure ranging from $37-85 \%$. The most common route of administration was intralesional local injection, with only one study using the intravenous route [56]. In 2015 Ciccocioppo et al reported the outcomes of 10 patients prospectively recorded over a period of 7 years. The probability of fistula relapse-free survival was $88 \%$ at 1 year, $50 \%$ at 2 years, and $37 \%$ with no adverse effects; supporting the effectiveness and long-term safety of this procedure [57]. More recently, a randomized phase III controlled trial has shown good effectiveness in patients who have failed conventional or biologic treatments [58]. This trial included 212 patients, randomized to receive intralesional injection of allogeneic adipose-derived stem cells or saline solution (placebo); fistula remission was higher in stem cells group at week 24 (50\% vs. $34 \%$, P 0.024). Though MSC therapy appears promising, there are still key questions to be answered, such as the ideal type of MSC, the dosage of cells required, the number of injections, and its long-term efficacy.

\section{Fibrin glue injection}

Fibrin glue injection is an attractive and simple technique that uses the activation of thrombin to form a fibrin clot that mechanically seals the fistula tract. The clot undergoes gradual fibrinolysis while activating tissue-healing mechanisms to permanently close the fistula tract. Uncontrolled reports showed encouraging results, with success rates ranging from $60-85 \%$ [59]. The most relevant study was published in 2010, when Grimaud et al performed a multicenter, open-label, randomized controlled trial that included 77 patients with a CD Activity Index (CDAI) score $\leq 250$ and fistulas between the anus (or low rectum) and perineum, vulva, or vagina, which drained for more than 2 months [60]. Clinical remission at week 8 was observed in $38 \%$ of the fibrin glue group compared with $16 \%$ in the observation group; the subgroup with complex fistulas obtained inferior results. The authors remarked on the patients' low CDAI score and hypothesized that fibrin glue is a purely mechanical treatment that should take place only after inflammation has been controlled.

\section{Anal fistula plug}

Currently there are two available methods: Surgisis ${ }^{\circledR}$ and GORE BioA ${ }^{\circledR}$ plug. The most widespread is Surgisis ${ }^{\circledR}$, a bioabsorbable plug composed of lyophilized porcine-derived small intestinal submucosa. The GORE BioA ${ }^{\circledR}$ plug is made of absorbable synthetic compounds with a cone-shaped design, fused to a flat disc at one end, in order to allow easy fixation at the internal fistula opening. A recent systematic review of the literature that included 8 nonrandomized prospective studies and 4 retrospective cohorts gathered 84 patients with an average age of 45 and a median follow-up time of 9 months. Overall, the success rates of Surgisis ${ }^{\circledR}$ and $\mathrm{GORE}^{\circledR} \mathrm{BIOA}^{\circledR}$ brand plugs were $48 / 80$ (60\%, 95\% CI $48-71 \%)$ and $1 / 4$ (25\%, 95\% CI 1-81\%) respectively; inferior results when compared with non-CD anal fistulas. The rate of recurrence was analyzed in 5 original papers $(13.6 \%)$. The success rate was inferior in those treated with preoperative immunomodulators [61].

These promising results have not been reproduced in the first multicenter, open-label, randomized controlled trial to date. In 2016 Senejoux et al compared the Surgisis ${ }^{\circledR}$ plug with seton removal alone (control group) in $106 \mathrm{CD}$ patients with non- or only mildly active disease. No difference was found in terms of fistula closure and adverse events [62].

\section{Fistula laser closure}

This is a new sphincter-saving technique that uses a diode laser $\left(\mathrm{FiLaC}^{\mathrm{TM}}\right)$ to destroy the fistula epithelium and obliterate the whole fistula tract. Laser energy promotes shrinkage of tissue and progressive sealing of fistulas. Wilhelm published the first pilot study in 2011 with 11 patients (none with IBD), achieving $81.8 \%$ primary fistula healing with only one minor adverse event [63]. Giamundo et al in 2015 carried out a retrospective single-institution study of 45 patients; two patients with PCD were successfully managed [64].

Carbon dioxide laser ablation therapy has also shown favorable results in small uncontrolled retrospective cohorts [65].

\section{Malignant transformation in perianal fistulas}

To our knowledge, no large population-based studies have been performed to assess the true prevalence of fistulaassociated anal carcinoma (FAAC). Available data are from case reports, retrospective cohorts and a systematic review of 2010 that compiled 61 cases $[66,67]$. This is considered 
an unusual entity, with an estimated prevalence of $0.004-$ $0.7 \%$ [68]. FAAC arises in patients with long-standing fistulas; most cases have been documented in subjects with a disease duration over 15 years. Its exact pathogenesis is unclear; it has been postulated that chronic inflammation, long-term immunosuppression, infection by human papillomavirus, and smoking may all be involved in its genesis [66,68,69]. Adenocarcinoma, particularly the mucin-producing variant, is by far the most common histological type; squamous cell carcinoma has also been reported [66]. The majority of tumors are diagnosed at an advanced stage, since FAAC is a rapidly developing malignancy and symptoms are usually absent or non-specific. Anal discharge, fistula draining, painful defecation or other worsening symptoms should all raise suspicion among patients with long-standing perianal disease and MRI/EUA should be considered. Some authors advocate yearly surveillance in patients with more than a 10 -year history of perianal disease [69]; however, others do not recommend this approach because of its low prevalence and the lack of a validated screening algorithm $[66,68]$.

Prognosis after surgery is usually poor, with a high rate of postoperative relapse, especially if perirectal lymph nodes are affected. Adjuvant chemoradiotherapy is highly controversial and its use should only be considered on an individual basis. There is no good evidence to support its routine use. In addition it has been suggested that mucinous adenocarcinoma does not respond to this therapy [69].

\section{Concluding remarks}

The management of CPCD requires the collaboration of radiologists, colorectal surgeons and gastroenterologists. Diagnosis should include a careful history and physical examination, but these must to be complemented. MRI and EUS are the mainstay of imaging evaluation, and EUA remains the gold standard for diagnosing and classifying this disease. The combination of EUA with MRI or EUS improves accuracy to reach $100 \%$. Before initiating immunosuppressive treatment, it is important to control sepsis with antibiotics, surgical drainage, or both. Associated proctitis, if present, must be treated to improve the effectiveness of other therapies. Despite the lack of controlled trials, antibiotics as adjuvant therapy to immunomodulators and surgical therapy are the recommended treatment for CPCD. Anti-TNF agents have the best available evidence record in the treatment of CPCD, so they can be used as the first-line treatment associated with surgical therapy.

The future perspectives in the area of perianal CD could probably come from two sources. We are getting the first data about new drugs in the management of $\mathrm{CD}$, and it would undoubtedly be a major bonus if any of them was revealed as especially active in this context. Data on the efficacy of vedolizumab and ustekinumab do not look especially bright, but new mechanisms of action are continuously being explored. The other possible source is the expansion of local therapies, and in this realm the use of stem cells seems the most likely source for positive results. Other more speculative domains could include the identification of a genetic predisposition to suffer perianal $C D$, advances in diagnostic techniques, and new studies on the long-term efficacy of therapeutic strategies (as opposed to single drugs, as is generally explored in pivotal studies). These patients carry a heavy personal burden, and their disease adds a significant burden to the spending on hospital consultations, drug therapy and surgery costs. Therefore, let us sincerely hope that the next years bring good news in the management of this condition.

\section{References}

1. Van Assche G, Dignass A, Panes J, et al; European Crohn's and Colitis Organisation (ECCO). The second European evidencebased Consensus on the diagnosis and management of Crohn's disease: Definitions and diagnosis. J Crohns Colitis 2010;4:7-27.

2. Chaparro M, Zanotti C, Burgueño $\mathrm{P}$, et al. Health care costs of complex perianal fistula in Crohn's disease. Dig Dis Sci 2013;58:3400-3406.

3. Van Assche G, Dignass A, Reinisch W, et al; European Crohn's and Colitis Organisation (ECCO). The second European evidencebased Consensus on the diagnosis and management of Crohn's disease: Special situations. J Crohns Colitis 2010;4:63-101.

4. Sandborn WJ, Fazio VW, Feagan BG, Hanauer SB; American Gastroenterological Association Clinical Practice Committee. AGA technical review on perianal Crohn's disease. Gastroenterology 2003; 125:1508-1530.

5. Bell SJ, Williams AB, Wiesel $\mathrm{P}$, Wilkinson $\mathrm{K}$, Cohen $\mathrm{RC}$, Kamm MA. The clinical course of fistulating Crohn's disease. Aliment Pharmacol Ther 2003;17:1145-1151.

6. Molendijk I, Nuij VJ, van der Meulen-de Jong AE, van der Woude CJ. Disappointing durable remission rates in complex Crohn's disease fistula. Inflamm Bowel Dis 2014;20:2022-2028.

7. Saro C, da la Coba C, Casado MA, Morales JM, Otero B. Resource use in patients with Crohn's disease treated with infliximab. Aliment Pharmacol Ther 2007;26:1313-1323.

8. Zwintscher NP, Shah PM, Argawal A, et al. The impact of perianal disease in young patients with inflammatory bowel disease. Int $J$ Colorectal Dis 2015;30:1275-1279.

9. Riss S, Schwameis K, Mittlböck M, et al. Sexual function and quality of life after surgical treatment for anal fistulas in Crohn's disease. Tech Coloproctol 2013;17:89-94.

10. Parks AG, Gordon PH, Hardcastle JD. A classification of fistula-inano. Br J Surg 1976;63:1-12.

11. Panes J, Bouhnik Y, Reinisch W, et al. Imaging techniques for assessment of inflammatory bowel disease: joint ECCO and ESGAR evidence-based consensus guidelines. J Crohns Colitis 2013;7:556-585.

12. Navarro-Luna A, García-Domingo MI, Rius-Macías J, MarcoMolina C. Ultrasound study of anal fistulas with hydrogen peroxide enhancement. Dis Colon Rectum 2004;47:108-114.

13. Zawadzki A, Starck M, Bohe M, Thorlacius H. A unique 3D endoanal ultrasound feature of perianal Crohn's fistula: the 'Crohn ultrasound fistula sign'. Colorectal Dis 2012;14:e608-e611.

14. Siddiqui MR, Ashrafian H, Tozer P, et al. A diagnostic accuracy meta-analysis of endoanal ultrasound and MRI for perianal fistula assessment. Dis Colon Rectum 2012;55:576-585.

15. Maconi G, Ardizzone S, Greco S, Radice E, Bezzio C, Bianchi Porro G. Transperineal ultrasound in the detection of perianal and rectovaginal fistulae in Crohn's disease. Am J Gastroenterol 2007;102:2214-2219. 
16. Schwartz DA, Wiersema MJ, Dudiak KM, et al. A comparison of endoscopic ultrasound, magnetic resonance imaging, and exam under anesthesia for evaluation of Crohn's perianal fistulas. Gastroenterology 2001;121:1064-1072.

17. Sahni VA, Ahmad R, Burling D. Which method is best for imaging of perianal fistula? Abdom Imaging 2008;33:26-30.

18. Gecse KB, Bemelman W, Kamm MA, et al; World Gastroenterology Organization International Organisation for Inflammatory Bowel Diseases IOIBD European Society of Coloproctology and Robarts Clinical Trials. A global consensus on the classification, diagnosis and multidisciplinary treatment of perianal fistulising Crohn's disease. Gut 2014;63:1381-1392.

19. Irvine EJ. Usual therapy improves perianal Crohn's disease as measured by a new disease activity index. McMaster IBD Study Group. J Clin Gastroenterol 1995;20:27-32.

20. Losco A, Viganò C, Conte D, Cesana BM, Basilisco G. Assessing the activity of perianal Crohn's disease: comparison of clinical indices and computer-assisted anal ultrasound. Inflamm Bowel Dis 2009;15:742-749.

21. Schwartz DA, Ghazi LJ, Regueiro M, et al; Crohn's \& Colitis Foundation of America, Inc. Guidelines for the multidisciplinary management of Crohn's perianal fistulas: summary statement. Inflamm Bowel Dis 2015;21:723-730.

22. Van Assche G, Vanbeckevoort D, Bielen D, et al. Magnetic resonance imaging of the effects of infliximab on perianal fistulizing Crohn's disease. Am J Gastroenterol 2003;98:332-339.

23. Makowiec F, Jehle EC, Becker HD, Starlinger M. Perianal abscess in Crohn's disease. Dis Colon Rectum 1997;40:443-450.

24. de Groof EJ, Sahami S, Lucas C, Ponsioen CY, Bemelman WA, Buskens CJ. Treatment of perianal fistula in Crohn's disease: a systematic review and meta-analysis comparing seton drainage and anti-tumour necrosis factor treatment. Colorectal Dis 2016;18:667-675.

25. Marzo M, Felice C, Pugliese D, et al. Management of perianal fistulas in Crohn's disease: an up-to-date review. World $J$ Gastroenterol 2015;21:1394-1403.

26. Hong MK, Craig Lynch A, Bell S, et al. Faecal diversion in the management of perianal Crohn's disease. Colorectal Dis 2011;13:171-176.

27. Pellino G, Selvaggi F. Surgical treatment of perianal fistulizing Crohn's disease: from lay-open to cell-based therapy. An overview. ScientificWorldJournal 2014;2014:146281.

28. Cattan P, Bonhomme N, Panis Y, et al. Fate of the rectum inpatients undergoing total colectomy for Crohn's disease. Br J Surg 2001;89:454-459.

29. Wang JY, Hart SL, Wilkowski KS, et al. Gender-specific differences in pelvic organ function after proctectomy for inflammatory bowel disease. Dis Colon Rectum 2011;54:66-76.

30. de Groof EJ, Cabral VN, Buskens CJ, Morton DG, Hahnloser D, Bemelman WA; research committee of the European Society of Coloproctology. Systematic review of evidence and consensus on perianal fistula: an analysis of national and international guidelines. Colorectal Dis 2016;18:O119-34.

31. Thia KT, Mahadevan U, Feagan BG, et al. Ciprofloxacin or metronidazole for the treatment of perianal fistulas in patients with Crohn's disease: a randomized, double-blind, placebo-controlled pilot study. Inflamm Bowel Dis 2009;15:17-24.

32. Dejaco C, Harrer M, Waldhoer T, Miehsler W, Vogelsang H, Reinisch W. Antibiotics and azathioprine for the treatment of perianal fistulas in Crohn's disease. Aliment Pharmacol Ther 2003; 18:1113-1120.

33. West RL, van der Woude CJ, Hansen BE, et al. Clinical and endosonographic effect of ciprofloxacin on the treatment of perianal fistulae in Crohn's disease with infliximab: a double-blind placebocontrolled study. Aliment Pharmacol Ther 2004;20:1329-1336.
34. Dewint P, Hansen BE, Verhey E, et al. Adalimumab combined with ciprofloxacin is superior to adalimumab monotherapy in perianal fistula closure in Crohn's disease: a randomised, double-blind, placebo controlled trial (ADAFI). Gut 2014;63:292-299.

35. Maeda Y, Ng SC, Durdey P, et al; Topical Metronidazole in Perianal Crohn's Study Group. Randomized clinical trial of metronidazole ointment versus placebo in perianal Crohn's disease. $\mathrm{Br}$ J Surg 2010;97:1340-1347.

36. Pearson DC, May GR, Fick GH, Sutherland LR. Azathioprine and 6-mercaptopurine in Crohn disease. A meta-analysis. Ann Intern Med 1995;123:132-142.

37. Sandborn WJ, Present DH, Isaacs KL, et al. Tacrolimus for the treatment of fistulas in patients with Crohn's disease: a randomized, placebo-controlled trial. Gastroenterology 2003;125:380-388.

38. Gerich ME, Pardi DS, Bruining DH, Kammer PP, Becker BD, Tremaine WT. Tacrolimus salvage in anti-tumor necrosis factor antibody treatment-refractory Crohn's disease. Inflamm Bowel Dis 2013;19:1107-1111.

39. Cat H, Sophani I, Lemann M, Modiglani R, Solue JC. Cyclosporin treatment of anal and perianal lesions associated with Crohn's disease. Turk J Gastroenterol 2003;14:121-127.

40. Mahadevan U, Marion JF, Present DH. Fistula response to methotrexate in Crohn's disease: a case series. Aliment Pharmacol Ther 2003; 18:1003-1008.

41. Yang C, Singh P, Singh H, Le ML, El-Matary W. Systematic review: thalidomide and thalidomide analogues for treatment of inflammatory bowel disease. Aliment Pharmacol Ther 2015;41:1079-1093.

42. Present DH, Rutgeerts P, Targan S, et al. Infliximab for the treatment of fistulas in patients with Crohn's disease. N Engl J Med 1999;340:1398-1405.

43. Sands BE, Anderson FH, Bernstein $\mathrm{CN}$, et al. Infliximab maintenance therapy for fistulizing Crohn's disease. $N$ Engl J Med 2004;350:876-885.

44. Schwartz DA, Ghazi LJ, Regueiro M. Guidelines for medical treatment of Crohn's perianal fistulas: critical evaluation of therapeutic trials. Inflamm Bowel Dis 2015;21:737-752.

45. Lichtenstein GR, Yan S, Bala M, Blank M, Sands BE. Infliximab maintenance treatment reduces hospitalizations, surgeries, and procedures in fistulizing Crohn's disease. Gastroenterology 2005; 128:862-869.

46. Ardizzone S, Maconi G, Colombo E, Manzionna G, Bollani S, Bianchi Porro G. Perianal fistulae following infliximab treatment: clinical and endosonographic outcome. Inflamm Bowel Dis 2004;10:91-96.

47. Yarur A, Kanagala V, Stein D, et al. Higher infliximab trough levels are associated with a higher rate of perianal fistula healing in patients with Crohn's disease. Gastroenterology 2016;4-1:S105-S106.

48. Colombel JF, Schwartz DA, Sandborn WJ, et al. Adalimumab for the treatment of fistulas in patients with Crohn's disease. Gut 2009;58:940-948.

49. Schreiber S, Lawrance IC, Thomsen O, Hanauer SB, Bloomfield R, Sandborn WJ. Randomised clinical trial: certolizumab pegol for fistulas in Crohn's disease - subgroup results from a placebocontrolled study. Aliment Pharmacol Ther 2011;33:185-193.

50. Sandborn WJ, Feagan BG, Rutgeerts P, et al; GEMINI 2 Study Group. Vedolizumab as induction and maintenance therapy for Crohn's disease. N Engl J Med 2013;369:711-721.

51. Simon EG, Ghosh S, Iacucci M, Moran GW. Ustekinumab for the treatment of Crohn's disease: can it find its niche? Therap $A d v$ Gastroenterol 2016;9:26-36.

52. Wils P, Bouhnik Y, Michetti P, et al; Groupe d'Etude Thérapeutique des Affections Inflammatoires du Tube Digestif. Subcutaneous ustekinumab provides clinical benefit for two-thirds of patients with Crohn's disease refractory to anti-tumor necrosis factor 
agents. Clin Gastroenterol Hepatol 2016;14:242-250.e1-e2.

53. Weisz G, Lavy A, Adir Y, et al. Modification of in vivo and in vitro TNF-alpha, IL-1, and IL-6 secretion by circulating monocytes during hyperbaric oxygen treatment in patients with perianal Crohn's disease. J Clin Immunol 1997;17:154-159.

54. Al-Waili NS, Butler GJ. Effects of hyperbaric oxygen on inflammatory response to wound and trauma: possible mechanism of action. Scientific WorldJournal 2006;6:425-441.

55. Dulai PS, Gleeson MW, Taylor D, Holubar SD, Buckey JC, Siegel CA. Systematic review: The safety and efficacy of hyperbaric oxygen therapy for inflammatory bowel disease. Aliment Pharmacol Ther 2014;39:1266-1275.

56. Garcia-Olmo D, Schwartz DA. Cumulative evidence that mesenchymal stem cells promote healing of perianal fistulas of patients with Crohn's disease-going from bench to bedside. Gastroenterology 2015;149:853-857.

57. Ciccocioppo R, Gallia A, Sgarella A, Kruzliak P, Gobbi PG, Corazza GR. Long-term follow-up of Crohn disease fistulas after local injections of bone marrow-derived mesenchymal stem cells. Mayo Clin Proc 2015;90:747-755.

58. Panés J, García-Olmo D, Van Assche G, et al. Expanded allogeneic adipose-derived mesenchymal stem cells (Cx601) for complex perianal fistulas in Crohn's disease: a phase 3 randomised, doubleblind controlled trial. Lancet 2016;388:1281-1290.

59. Vitton V, Gasmi M, Barthet M, Desjeux A, Orsoni P, Grimaud JC. Long-term healing of Crohn's anal fistulas with fibrin glue injection. Aliment Pharmacol Ther 2005;21:1453-1457.

60. Grimaud JC, Munoz-Bongrand N, Siproudhis L, et al; Groupe d'Etude Thérapeutique des Affections Inflammatoires du Tube Digestif. Fibrin glue is effective healing perianal fistulas in patients with Crohn's disease. Gastroenterology 2010;138:2275-2281, 2281.e1.
61. Nasseri Y, Cassella L, Berns M, Zaghiyan K, Cohen J. The anal fistula plug in Crohn's disease patients with fistula-in-ano: a systematic review. Colorectal Dis 2016;18:351-356.

62. Senéjoux A, Siproudhis L, Abramowitz L, et al.; Groupe d'Etude Thérapeutique des Affections Inflammatoires du tube Digestif [GETAID]. Fistula plug in fistulising ano-perineal Crohn's disease: a randomised controlled trial. J Crohns Colitis 2016;10:141-148.

63. Wilhelm A. A new technique for sphincter-preserving anal fistula repair using a novel radial emitting laser probe. Tech Coloproctol 2011;15:445-449.

64. Giamundo P, Esercizio L, Geraci M, Tibaldi L, Valente M. Fistulatract laser closure $\left(\mathrm{FiLaC}^{\mathrm{m}}\right)$ : long-term results and new operative strategies. Tech Coloproctol 2015;19:449-453.

65. Moy J, Bodzin J. Carbon dioxide laser ablation of perianal fistulas in patients with Crohn's disease: experience with 27 patients. $A m \mathrm{~J}$ Surg 2006;191:424-427.

66. Thomas M, Bienkowski R, Vandermeer TJ, Trostle D, Cagir B. Malignant transformation in perianal fistulas of Crohn's disease: a systematic review of literature. J Gastrointest Surg 2010;14:66-73.

67. Baars JE, Kuipers EJ, Dijkstra G, et al; Initiative for Crohn and Colitis. Malignant transformation of perianal and enterocutaneous fistulas is rare: results of 17 years of follow-up from The Netherlands. Scand J Gastroenterol 2011;46:319-325.

68. Alcalde-Vargas A, Trigo-Salado C, Leo-Carnerero E, CastellMonsalve FJ, Mateo-Vico O, Márquez-Galán JL. Severe perianal disease degenerated to adenocarcinoma. Is close monitoring of long-term perianal disease necessary? Rev Esp Enferm Dig 2013;105:115-116.

69. Iesalnieks I, Gaertner WB, Glass H, et al. Fistula-associated anal adenocarcinoma in Crohn's disease. Inflamm Bowel Dis 2010;16:1643-1648. 